\title{
Oral creatine supplementation attenuates muscle loss caused by limb immobilization: a systematic review
}

\author{
Suplementação oral de creatina atenua a perda de massa muscular \\ causada pela imobilização de membros: uma revisão sistemática
}

\author{
Camila Souza Padilha, Paola Sanches Cella, Leo Rodrigues Salles, Rafael Deminice ${ }^{*}$
}

Universidade Estadual de Londrina (UEL), Londrina, PR, Brazil

\begin{abstract}
Introduction: Recent studies have pointing creatine supplementation as a promising therapeutic alternative in several diseases, especially myopathies and neurodegenerative disorder. Objective: elucidate the role of creatine supplementation on deleterious effect caused by limb immobilization in humans and rats. Methods: Analyzed articles were searched by three online databases, PubMed, SportDicus e Scielo. After a review and analysis, the studies were included in this review articles on effect of creatine supplementation on skeletal muscle in humans and rat, before, during and after a period of limb immobilization. Results: Studies analyzed demonstrated positive points in use of creatine supplementation as a therapeutic tool to mitigating the deleterious effects of limb immobilization, in humans and rat. Conclusion: The dataset of this literature review allows us to conclude that creatine supplementation may reduce muscle loss and/or assist in the recovery of muscle atrophy caused by immobilization and disuse in rats and humans. Also, we note that further research with better methodological rigor is needed to clarify the mechanisms by which creatine support the recovery of muscle atrophy. Moreover, these effects are positive and promising in the field of muscle rehabilitation, especially after member's immobilization.
\end{abstract}

Keywords: Creatine. Immobilization. Atrophic Muscular Disorders.

\footnotetext{
* CSP: Doctoral student, e-mail: camilapersonal@yahoo.com.br

PSC: Master student, e-mail: paolascella@gmail.com

LRS: BS, e-mail: leorsalles@yahoo.com.br

RD: PhD, e-mail: rdeminice@uel.br
} 
Resumo

Introdução: Estudos recentes apontam a suplementação de creatina como promissora alternativa terapêutica em desordens de diversos tipos, especialmente miopatias e desordens neurodegenerativas. Objetivo: Essa revisão tem o objetivo de elucidar o papel da creatina sobre a perda da massa muscular causada pela imobilização de membros em seres humanos e ratos. Métodos: Os artigos analisados foram buscados em três bases de dados on-line, PubMed, SportDiscus e Scielo. Após análise dos estudos, foram incluídos na presente revisão os efeitos da suplementação de creatina na musculatura esquelética, envolvendo seres humanos e roedores, antes, durante e depois de um período de imobilização e desuso. Resultados: Os estudos analisados apresentaram pontos positivos sobre a utilização de creatina, sobretudo quando combinado com outro recurso terapêutico, atenuando a atrofia muscular causada pela imobilização de membros. Conclusão: Em suma, o conjunto de dados ainda que limitantes apresentado por essa revisão de literatura nos permite concluir que a suplementação com creatina é capaz de amenizar a perda de massa muscular e/ou auxiliar na recuperação da atrofia muscular causada pela imobilização e desuso em ratos e humanos. Ainda, salientamos que mais investigações com melhor rigor metodológico são necessárias para o esclarecimento sobre os mecanismos pelo qual a creatina favorece a recuperação da atrofia muscular. Alem disso, esses efeitos são positivos e promissores na área da reabilitação muscular, especialmente após a imobilização de membros.

Palavras-chave: Creatina. Imobilização. Transtornos Musculares Atróficos.

\section{Introduction}

The reduction of muscular cross-sectional area is one of major deleterious effects caused by disuse, aging, limb immobilization or spinal cord injury, commonly known as muscle atrophy. Muscle atrophy is related with physiological and metabolically changes, such as, decreased sensor motor excitability, contractile ability of muscle fibers, protein degradation and depletion of energy stores, in which may promote weakness, reduced functional capacity and hindering the activities of daily living $(1-3)$.

Immobilization is an effective therapeutic resource and widely used for facilitating the healing of damaged tissue, giving them the potential to repair without outside interference. However, this strategy may cause decreased neural plasticity, displaying an abnormality in the path of the electrical stimulus, which impairs directly in the recruitment of muscle fibers. Added to this, the reduction of these stimuli may result in exaggerated amount of calcium in the sarcoplasmic reticulum, leading consequently to modify the feedback mechanism that determines the changes in the motor cortex reception ( 4 - 7). In view of this scenario, the use of creatine supplementation is a strategy that has been adopted to alleviate muscle disorders $(8-11)$.
Creatine is a compound naturally present in meat and fish, normally obtained through diet and / or synthesized by the body using the amino acids arginine, glycine and methionine $(12,13)$. On an omnivore diet, usually $1 \mathrm{~g}$ of creatine ids ingested per day, half the daily requirement. The other half comes from endogenous synthesis of this compound, in the liver, kidneys and pancreas $(12,14,15)$. Creatine is mainly stored in skeletal muscle (95\%) and phosphorylated in the free form and also in brain and testis (16). Due to its possible effects on physical performance, creatine has become a popular substance among amateur athletes, professional and Olympic. Since Harris et al. (17) showed that creatine supplementation increases intramuscular concentration of this compound numerous works has studied creatine supplementation in sports due to its possible effects on physical performance $(17-19)$.

In recent years, this compound has received considerable attention in the medical field, especially for introducing therapeutic effects of myopathies and neurodegenerative diseases caused by various diseases $(8,20-23)$. Recent studies show that creatine supplementation can increase strength and fat-free mass in patients with muscular dystrophy different causes $(20,21)$. Furthermore, these authors suggest that several mechanisms may contribute to the creatine beneficial 
effects, such as increased energy potential of cells and preserve muscle glycogen, act as antioxidant, reducing muscle calcium levels and reduce apoptosis. In 2004, Tarnopolsky found that creatine supplementation improves strength and body composition in patients with Duchenne's muscular dystrophy (24). Few years later, in 2007, in a meta-analysis with 12 trials and 266 participants (22) and in 2013, the same authors have made an update of the review and concluded that creatine supplementation can increase strength and muscle mass in patients with muscular dystrophy (22). Based on these results, the authors have sought to understand the potential therapeutic role of creatine on muscle atrophy caused by immobilization $(3,12,25-29)$. Thus, we emphasize the importance of systematic search in order to remedy the lack of discussion and consensus on the issue and address the possible mechanisms that creatine participates in mitigating the loss of muscle mass. Therefore, the aim of this study was, through a systematic review; analyze the role of creatine supplementation on loss of muscle mass caused by immobilizing members.

\section{Methods}

This study is a systematic literature review. Among the articles reviewed were prioritized the most important studies of the last 22 years (1992 - 2014), since Harris et al. (17) have shown that creatine supplementation increases intramuscular concentration of this compound. Studies were identified "on line" through the databases PubMed, SportDicus and Scielo. Portuguese and English publications were analyzed using the keywords "Hindlimb" OR "Hypokinesia" OR "Immobilization" AND "Oral Creatine Supplementation". Articles cited in other studies were identified and included in this study, when met the inclusion criteria. We selected only those studies which compared the effects of creatine supplementation on skeletal muscle involving humans and rodents, before, during and / or after a period of disuse and immobilization. Studies that treat muscle dysfunction nate or innate were excluded. Figure 1 outlines the refinement and selection of articles studied.

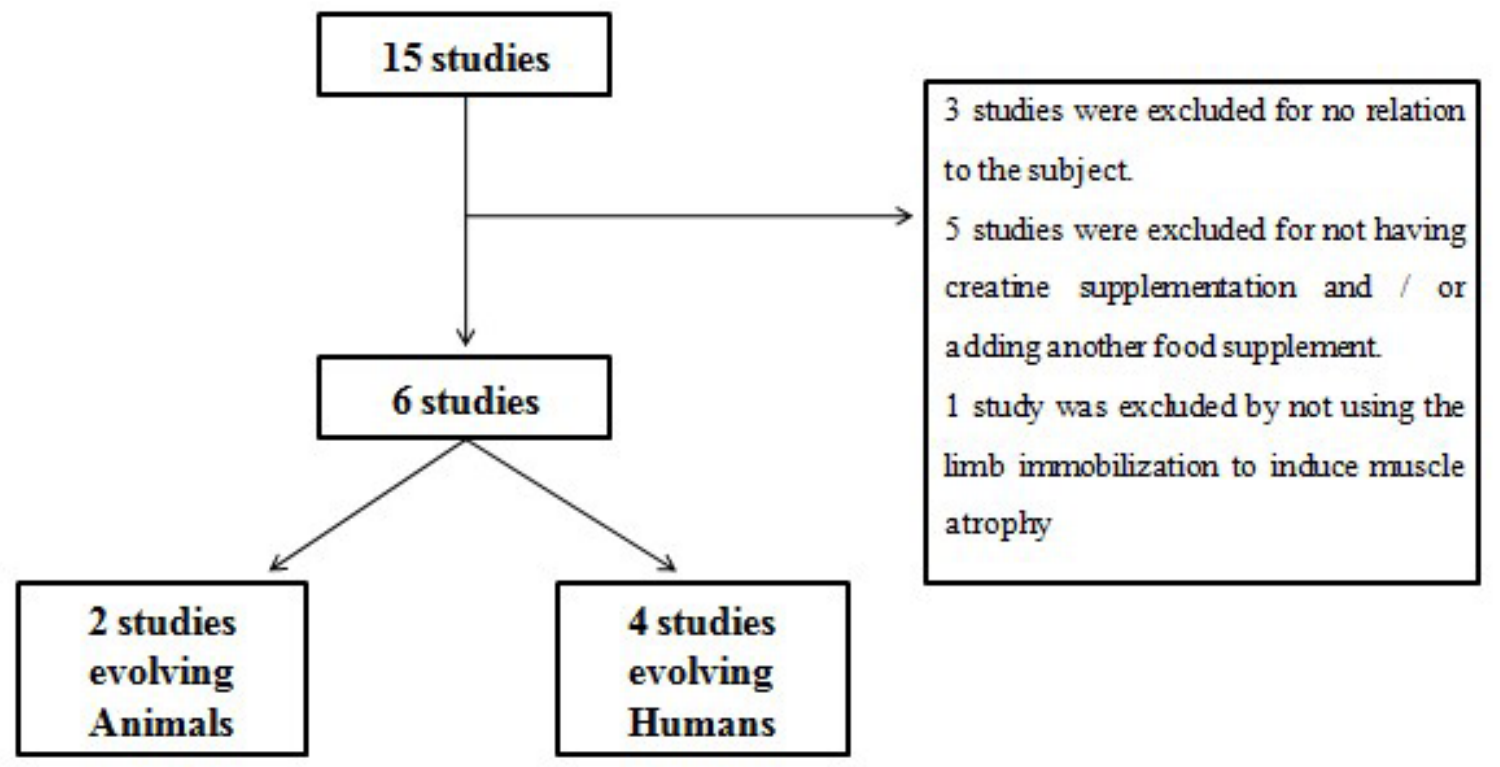

Figure $\mathbf{1}$ - Procedures for inclusion of studies in this systematic review.

We used the PEDro table (Physiotherapy Evidence Database) (http://www.pedro.org.au/portuguese) to evaluate the level of evidence and objectivity of studies in humans. The scoring system has been adjusted to better match the theme of the work, since the design of the studies has particular characteristics compared to physiotherapy studies, the main purpose of PEDro table. The adapted system has score 0-8 points. Studies containing less than 5 points were excluded from analysis. The quality criteria were used to guide users to quickly identify the studies and their relevance (Table 1). 
Table 1 - Scoring system used in the study and the score of four articles reviewed in humans

\begin{tabular}{llllllll}
\hline Evaluated aspects & $\mathbf{1}$ & $\mathbf{2}$ & $\mathbf{3}$ & $\mathbf{4}$ & $\mathbf{5}$ & $\mathbf{6}$ & $\mathbf{7}$ \\
\hline Eijnde et al. 2001 & 0 & 2 & 1 & 1 & 0 & 1 & 5 \\
Hespel et al. 2001 & 1 & 2 & 1 & 1 & 1 & 1 & 7 \\
Eijnde et al. 2005 & 1 & 2 & 1 & 1 & 1 & 0 & 6 \\
Johnston et al. 2009 & 1 & 2 & 1 & 0 & 1 & 1 & 6 \\
\hline
\end{tabular}

Note: Evaluation studies found according to an adaptation table PEDro (developed by the Physiotherapy Evidence Database). 1) Random of groups; 2) Control supplementation (double-blind, placebocontrolled and crossover); 3) Similarity of the groups in the initial or baseline; 4) Determination intramuscular creatine; 5) Other controls (criteria for the non-use of creatine provided); 6)Time of immobilization (if the detention was able to generate losses in the control group); 7 ) Total points.

\section{Results}

For selection and characterization, 15 studies were evaluated for the inclusion criteria, of which 6 were selected (Figure 1). Table 2 shows the characteristics of the six studies included in this review. The most relevant points of each study were highlighted, such as, random of the groups, control supplementation (double-blind, placebo-controlled), similarity of groups at baseline determination of intramuscular creatine, other controls (criteria for non-use provided creatine), time of immobilization (if the detention was able to generate losses in the control group) and total points.

Among the studies included in the review, two were conducted with rodents and other four with humans. The earliest study was 2001 , so nine years after the publication of Harris et al. (17). The analyzed data points favorable to the therapeutic use of creatine as a new approach on loss of muscle mass caused by immobilizing members.

Table 2 - Characteristics of studies in humans and rodents included in this review

\begin{tabular}{|c|c|c|c|c|}
\hline Author- Year & Immobilization & $\begin{array}{l}\text { Supplementation } \\
\text { protocol }\end{array}$ & Dosage & Results \\
\hline $\begin{array}{l}\text { Aoki et al. } \\
2004\end{array}$ & hind paw, 7 days & $\begin{array}{l}\text { Creatine added in the } \\
\text { drinking water, ad } \\
\text { libitum }\end{array}$ & $\begin{array}{l}5 \mathrm{~g} / \mathrm{kg} / \text { day for } 3 \text { doses. Divided } \\
\text { into } 4 \text { groups, } 3 \text { with } \mathrm{n}=6 \text { and } \\
1 \text { with } \mathrm{n}=12 \text { (control). } 7 \text { e } 14 \\
\text { days }\end{array}$ & $\begin{array}{l}\text { Cr before immobilization } \\
\text { minimizes muscle loss. And } \\
\text { after immobilization improved } \\
\text { muscle gain. }\end{array}$ \\
\hline $\begin{array}{l}\text { Silva et al. } \\
2006\end{array}$ & hind paw, 7 days & Intragastric gavage & $1,6 \mathrm{~g} \cdot \mathrm{kg}-1 \cdot \mathrm{d}-1,7$ days & $\begin{array}{l}\text { Improved energy conditions } \\
\text { in normal and immobilized } \\
\text { muscles, as well as anti- } \\
\text { catabolic action disuse }\end{array}$ \\
\hline $\begin{array}{l}\text { Johnston et al. } \\
2009\end{array}$ & $\begin{array}{l}\text { upper limb flexion } 90 \\
{ }^{\circ} \text { elbow, } 7 \text { days. }\end{array}$ & $\begin{array}{l}\text { Single-blind, control } \\
\text { group / placebo, } \\
\text { crossover, } 7 \text { men, } \\
\text { average of } 22 \text { years old. }\end{array}$ & $20 \mathrm{~g}$ daily for 7 days. & $\begin{array}{l}\text { Cr attenuated loss of muscle } \\
\text { mass and strength during } \\
\text { immobilization in humans, } \\
\text { regardless of training. }\end{array}$ \\
\hline $\begin{array}{l}\text { Op't Eijnde et al. } \\
2005\end{array}$ & $\begin{array}{l}\text { lower limb } 160^{\circ} \text { knee } \\
14 \text { days. }\end{array}$ & $\begin{array}{l}\text { Double-blind, } 19 \text { men } \\
\text { and } 3 \text { women average } \\
18-30 \text { years old. Group } \\
\text { control / placebo }\end{array}$ & $\begin{array}{l}15 \mathrm{~kg} / \text { day for } 14 \text { days } \\
\text { immobilization; } 2.5 \mathrm{~g} / \mathrm{d} 6 \text { weeks } \\
\text { of rehabilitation }\end{array}$ & $\begin{array}{l}\text { The effects of } \mathrm{Cr} \text { during } \\
\text { immobilization and training } \\
\text { are not related to AMPK. }\end{array}$ \\
\hline $\begin{array}{l}\text { Hespel et al. } \\
2001\end{array}$ & $\begin{array}{l}\text { lower limb } 160^{\circ} \text { knee } \\
14 \text { days. }\end{array}$ & $\begin{array}{l}\text { Double-blind, } 13 \text { men } \\
\text { and } 9 \text { women, average } \\
20-23 \text { years old.Group } \\
\text { control / placebo. }\end{array}$ & $\begin{array}{l}\text { Cr and Pla } 20 \mathrm{~g} / \text { day } \\
\text { immobilization } 14 \text { days; } 15 \mathrm{~g} / \\
\text { day } 1-3 \text { week rehabilitation; } 5 \\
\mathrm{~g} / \text { day of the } 3-10 \text { week after } \\
\text { immobilization. }\end{array}$ & $\begin{array}{l}\text { Cr improves muscle } \\
\text { hypertrophy and the } \\
\text { rehabilitation process. } \\
\text { Changed factors of myogenic } \\
\text { and MRF4 protein. }\end{array}$ \\
\hline $\begin{array}{l}\text { Op`t Eijnde et al. } \\
2001\end{array}$ & $\begin{array}{l}\text { lower limb } 160^{\circ} \text { knee } \\
14 \text { days. }\end{array}$ & $\begin{array}{l}\text { Double-blind, } 13 \text { men } \\
\text { and } 9 \text { women, average } \\
20-23 \text { years old.Group } \\
\text { control / placebo. }\end{array}$ & $\begin{array}{l}\text { Cr and Pla } 20 \mathrm{~g} / \text { day } \\
\text { immobilization } 14 \text { days; } 15 \mathrm{~g} \text { / } \\
\text { day } 1-3 \text { week rehabilitation; } 5 \\
\mathrm{~g} / \text { day of the } 3-10 \text { week after } \\
\text { immobilization. }\end{array}$ & $\begin{array}{l}\text { Cr maintained GLUT4 during } \\
\text { immobilization and increased } \\
\text { in rehabilitation training. }\end{array}$ \\
\hline
\end{tabular}




\section{Discussion}

The main findings of this systematic review were: 1) creatine supplementation is able to mitigate the loss and / or assist in the recovery of muscle atrophy caused by immobilization and disuse in mice and humans; 2) start supplementation immediately with immobilization and / or the rehabilitation process are the main ways to achieve positive results; 3) numerous mechanisms have been linked to these beneficial effects, however, the exact mechanism by which creatine supplementation alleviates muscle atrophy caused by immobilization is still unknown.

In recent years creatine has received considerable attention in the medical field, especially for introducing therapeutic effects of myopathies and neurodegenerative diseases caused by various diseases. Two recent reviews $(22,30)$ discuss the potential beneficial effect of creatine supplementation in several diseases, besides the aforementioned, including: cancer, diabetes, depression, osteoarthritis, dyslipidemia, among others. These authors conclude that creatine is a promising nutritional compound in the medical field. From the 6 studies included in this review, two animals used as experimental model. Aoki et al. (25) demonstrated that 14 days of creatine supplementation $15 \mathrm{~g} / \mathrm{kg}$ of creatine added to the diet for 7 days before and 7 days during immobilization) had reduced the mass loss of soleus and gastrocnemius muscle after 7 days of immobilization of hind paws. These authors have also shown that creatine alleviates change in the pattern of muscle fibers caused by immobilization. These changes are associated with increased concentrations of creatine intramuscularly, approximately 25\%.Similar results were found by Cancelliero and Silva $(13,31)$ concluded that creatine supplementation ( 7 days $1.6 \mathrm{~g}$. $\mathrm{kg}-1 \cdot \mathrm{d}-1$, available in drinking water) minimized the loss of mass of the soleus muscle and retained glycogen content after 7 days of immobilized hind paw. These results suggest that creatine supplementation may minimize changes in energy metabolism triggered by immobilization, a fact that possibly favors faster recovery after immobilization.

Noting the applicability of this strategy, human studies confirm the therapeutic potential of creatine supplementation on muscle mass loss induced by immobilizing members. The study Hespel et al. (3) was a pioneer in testing this potential. Healthy young volunteers had immobilized the right leg for 2 weeks, followed by a 10 weeks rehabilitation program, divided into groups supplemented with creatine $(20$ to $5 \mathrm{~g} /$ day) and placebo substance. The immobilization period caused a decrease in cross-sectional area $(10 \%)$ of the quadriceps similar between groups. In contrast, the rehabilitation program provided more efficient results when combined with creatine supplementation. The authors demonstrated an increase in MRF4 protein concentration of only creatine group, in addition to narrow correlation with the increase in muscle fiber size. Studies with rats have shown that such factors are involved in the catabolic process and muscle anabolism $(3,26$, 32,33 ). Similar results were found in two studies conducted by the group of Eijinde et al. $(27,28)$. In a study published in 2001 (27) these authors have shown that creatine supplementation prevents the reduction and increase $(\sim 40 \%)$ the protein content of GLUT4 (glucose transporter protein in cells) after 15 days of immobilization and for 10 weeks recovery, respectively. These authors also found an increase in muscle glycogen concentration during the rehabilitation period for the creatine group compared to placebo. Some years later, the same group of authors (28) demonstrated that supplementation with creatine does not modulate the action of AMPK (the enzyme which plays an important role in energy homeostasis of the cells), and that this mechanism does not explain the benefits attributed to AMPK in the immobilization. Johnston et al. (29) as the only one to analyze the immobilization of the upper limbs; and demonstrated that 7 days of creatine supplementation ( $4 \times 5 \mathrm{~g} /$ day) attenuated weight loss and reduction in muscle strength after 7 days of immobilization. These authors concluded that creatine supplementation can be used to accelerate the rehabilitation process of muscle atrophy caused by immobilization due to any accident or disease.

Despite all the studies presented in this review suggest positive aspects of creatine supplementation, the exact mechanism by which this compound alleviates / reverses muscle atrophy caused by immobilization is still unknown. Perhaps the most latent mechanism shown by this set of studies is the ability of guanidine compounds (such as creatine) to modulate glucose uptake and energy metabolism (34 - 37). Increased protein content of GLUT4 and conservation / increase in muscle glycogen content are indicated by some studies as the main mechanisms related to prevention of muscle mass, given 
creatine supplementation $(13,31)$. The number and capacity of translocation of GLUT4 protein is an important determinant of glucose transport through the cell plasma, so it's increased influence directly the concentration of muscle glycogen. Eijinde et al. (27) demonstrated that increased muscle creatine is able to improve GLUT4 content, regardless of training. After period of disuse, the placebo group showed a $20 \%$ decreased in GLUT4. Thus, the increase in the content of GLUT4 could reflect improvement in insulin sensitivity and cell anabolism pathway activation $(27,38)$. Another proposed mechanism discussed for increasing muscle mass is the concentration of intracellular water, responsible to enhance the cell hydration state. This effect may be related to increase protein synthesis, besides increases the expression of myogenic transcription factors $(26,28,39,40)$. However, the mechanisms by which creatine exerts beneficial effects in the immobilization are poorly understood. Although the number of studies included in this review added to the methodological weakness of some studies unable us to perform a statistical analysis in order to increase the level of evidence on the effectiveness of creatine supplementation, and also highlight the exact mechanism by which creatine supplementation alleviates muscle atrophy caused by immobilization.

\section{Conclusion}

In conclusion, the review allows us to conclude that creatine supplementation minimize the loss of muscle mass and / or assist in the recovery of muscle atrophy caused by immobilization and disuse in rats and humans. Moreover, we note that further research with better methodological rigor is needed to clarify the mechanisms by which creatine promotes the recovery of muscle atrophy. These effects are positive and promising in the field of muscle rehabilitation, especially after immobilizing members.

\section{References}

1. Nabuurs CI, Choe CU, Veltien A, Kan HE, van Loon LJ, Rodenburg RJ, et al. Disturbed energy metabolism and muscular dystrophy caused by pure creatine deficiency are reversible by creatine intake. J Physiol. 2013;591(Pt 2):571-92.
2. Reardon TF, Ruell PA, Fiatarone Singh MA, Thompson $\mathrm{CH}$, Rooney KB. Creatine supplementation does not enhance submaximal aerobic training adaptations in healthy young men and women. Eur J Appl Physiol. 2006;98(3):234-41.

3. Hespel P, Op't Eijnde B, Van Leemputte M, Urs $\varnothing$ B, Greenhaff PL, Labarque V, et al. Oral creatine supplementation facilitates the rehabilitation of disuse atrophy and alters the expression of muscle myogenic factors in humans. J Physiol. 2001;536(Pt 2):625-33.

4. Moisello C, Bove M, Huber R, Abbruzzese G, Battaglia F, Tononi G, et al. Short-term limb immobilization affects motor performance. J Mot Behav. 2008;40(2):165-76.

5. Zanette G, Tinazzi M, Bonato C, di Summa A, Manganotti $\mathrm{P}$, Polo A, et al. Reversible changes of motor cortical outputs following immobilization of the upper limb. Electroencephalogr Clin Neurophysiol. 1997;105(4):269-79.

6. Zanette G, Manganotti P, Fiaschi A, Tamburin S. Modulation of motor cortex excitability after upper limb immobilization. Clin Neurophysiol. 2004;115(6):1264-75.

7. Allen DG, Kabbara AA, Westerblad H. Muscle fatigue: the role of intracellular calcium stores. Can J Appl Physiol. 2002;27(1):83-96.

8. Gualano B, Artioli GG, Poortmans JR, Lancha Junior $\mathrm{AH}$. Exploring the therapeutic role of creatine supplementation. Amino Acids. 2010;38(1):31-44.

9. Gualano B, Ferreira DC, Sapienza MT, Seguro AC, Lancha AH. Effect of short-term high-dose creatine supplementation on measured GFR in a young man with a single kidney. Am J Kidney Dis. 2010;55(3):e7-9.

10. Alves CR, Santiago BM, Lima FR, Otaduy MC, Calich $\mathrm{AL}$, Tritto AC, et al. Creatine supplementation in fibromyalgia: a randomized, double-blind, placebo-controlled trial. Arthritis Care Res (Hoboken). 2013;65(9):1449-59.

11. Lynch GS, Schertzer JD, Ryall JG. Therapeutic approaches for muscle wasting disorders. Pharmacology and Therapeutics. 2007;113(3):461-87.

12. Silva RP, Nissim I, Brosnan ME, Brosnan JT. Creatine synthesis: hepatic metabolism of guanidinoacetate and creatine in the rat in vitro and in vivo. Am J Physiol Endocrinol Metab. 2009;296(2):E256-61. 
13. Cancelliero KM, Durigan JL, Vieira RP, Silva CA, Polacow ML. The effect of a low dose of clenbuterol on rat soleus muscle submitted to joint immobilization. Braz J Med Biol Res. 2008;41(12):1054-8.

14. Williams A, Sun X, Fischer JE, Hasselgren PO. The expression of genes in the ubiquitin-proteasome proteolytic pathway is increased in skeletal muscle from patients with cancer. Surgery. 1999;126(4):7449; discussion 9-50.

15. Williams MH, Branch JD. Creatine supplementation and exercise performance: an update. J Am Coll Nutr. 1998;17(3):216-34.

16. Wyss M, Kaddurah-Daouk R. Creatine and creatinine metabolism. Physiol Rev. 2000;80(3):1107-213.

17. Harris RC, Söderlund K, Hultman E. Elevation of creatine in resting and exercised muscle of normal subjects by creatine supplementation. Clin Sci (Lond). 1992;83(3):367-74.

18. Claudino JG, Mezêncio B, Amaral S, Zanetti V, Benatti F, Roschel H, et al. Creatine monohydrate supplementation on lower-limb muscle power in Brazilian elite soccer players. J Int Soc Sports Nutr. 2014;11:32.

19. Lugaresi R, Leme M, Painelli VS, Murai IH, Roschel H, Sapienza MT, et al. Does long-term creatine supplementation impair kidney function in resistance-trained individuals consuming a high-protein diet? J Int Soc Sports Nutr. 2013;10(1):26.

20. Tarnopolsky MA. Creatine as a therapeutic strategy for myopathies. Amino Acids. 2011;40(5):1397-407.

21. Tarnopolsky M, Martin J. Creatine monohydrate increases strength in patients with neuromuscular disease. Neurology. 1999;52(4):854-7.

22. Kley RA, Vorgerd M, Tarnopolsky MA. Creatine for treating muscle disorders. Cochrane Database Syst Rev. 2007(1):CD004760.

23. Solis MY, Hayashi AP, Artioli GG, Roschel H, Sapienza MT, Otaduy MC, et al. Efficacy and safety of creatine supplementation in juvenile dermatomyositis: A randomized, double-blind, placebo-controlled crossover trial. Muscle Nerve. 2016;53(1):58-66.

24. Tarnopolsky MA, Mahoney DJ, Vajsar J, Rodriguez C, Doherty TJ, Roy BD, et al. Creatine monohydrate enhances strength and body composition in Duchenne muscular dystrophy. Neurology. 2004;62(10):1771-7.
25. Aoki MS, Lima WP, Miyabara EH, Gouveia CH, Moriscot AS. Deleteriuos effects of immobilization upon rat skeletal muscle: role of creatine supplementation. Clin Nutr. 2004;23(5):1176-83.

26. Dangott B, Schultz E, Mozdziak PE. Dietary creatine monohydrate supplementation increases satellite cell mitotic activity during compensatory hypertrophy. Int J Sports Med. 2000;21(1):13-6.

27. Op 't Eijnde B, Ursø B, Richter EA, Greenhaff PL, Hespel P. Effect of oral creatine supplementation on human muscle GLUT4 protein content after immobilization. Diabetes. 2001;50(1):18-23.

28. Eijnde BO, Derave W, Wojtaszewski JF, Richter EA, Hespel P. AMP kinase expression and activity in human skeletal muscle: effects of immobilization, retraining, and creatine supplementation. J Appl Physiol (1985). 2005;98(4):1228-33.

29. Johnston AP, Burke DG, MacNeil LG, Candow DG. Effect of creatine supplementation during cast-induced immobilization on the preservation of muscle mass, strength, and endurance. J Strength Cond Res. 2009;23(1):116-20.

30. Kley RA, Tarnopolsky MA, Vorgerd M. Creatine for treating muscle disorders. Cochrane Database Syst Rev. 2013(6):CD004760.

31. Silva CA, Pardi ACR, Severi MTM, Martins T, Arruda E. Perfil energético do músculo esquelético de ratos suplementados com creatina na fase aguda da imobilização. Rev Eletronica Farm. 2009;6(4):99-113.

32. Koyama S, Hata S, Witt CC, Ono Y, Lerche S, Ojima $\mathrm{K}$, et al. Muscle RING-finger protein-1 (MuRF1) as a connector of muscle energy metabolism and protein synthesis. J Mol Biol. 2008;376(5):1224-36.

33. Roschel H, Gualano B, Marquezi M, Costa A, Lancha AH. Creatine supplementation spares muscle glycogen during high intensity intermittent exercise in rats. J Int Soc Sports Nutr. 2010;7(1):6.

34. Marco J, Calle C, Hedo JA, Villanueva ML. Glucagonreleasing activity of guanidine compounds in mouse pancreatic islets. FEBS Lett. 1976;64(1):52-4.

35. Schiaffino S, Dyar KA, Ciciliot S, Blaauw B, Sandri M. Mechanisms regulating skeletal muscle growth and atrophy. FEBS J. 2013;280(17):4294-314. 
36. Alsever RN, Georg RH, Sussman KE. Stimulation of insulin secretion by guanidinoacetic acid and other guanidine derivatives. Endocrinology. 1970;86(2):332-6.

37. Cooper R, Naclerio F, Allgrove J, Jimenez A. Creatine supplementation with specific view to exercise/ sports performance: an update. J Int Soc Sports Nutr. 2012;9(1):33.

38. Newman JE, Hargreaves M, Garnham A, Snow RJ. Effect of creatine ingestion on glucose tolerance and insulin sensitivity in men. Med Sci Sports Exerc. 2003;35(1):69-74.

39. Alves CR, Ferreira JC, Siqueira-Filho MA, Carvalho CR, Lancha AH, Gualano B. Creatine-induced glucose uptake in type 2 diabetes: a role for AMPK- $\alpha$ ? Amino Acids. 2012;43(4):1803-7.
40. del Favero S, Roschel H, Artioli G, Ugrinowitsch C, Tricoli V, Costa A, et al. Creatine but not betaine supplementation increases muscle phosphorylcreatine content and strength performance. Amino Acids. 2012;42(6):2299-305.

Received in $07 / 27 / 2015$ Recebido em 27/07/2015

Approved in 08/11/2016 Aprovado em 11/08/2016 